Sains Malaysiana 50(10)(2021): 2899-2911

http://doi.org/10.17576/jsm-2021-5010-05

\title{
Microplastic Abundance in Blood Cockles and Shrimps from Fishery Market, Songkhla Province, Southern Thailand
}

(Kelimpahan Mikroplastik dalam Kerang Darah dan Udang dari Pasar Ikan, Wilayah Songkhla, Selatan Thailand)

\author{
Patricia Blair Goh, Siriporn Pradit*, Prawit Towatana, Somkiat Khokkiatiwong, Butchanok \\ KONGKET \& JULIA HWEI ZHONG MOH
}

\begin{abstract}
Microplastics have been one of the major pollutants in the marine environment throughout the recent decade. At present, microplastic contamination in marine ecosystems of Thailand region has become an increasing environmental concern because the ingestion of microplastics in marine organisms may adversely influence the safety of seafood. Cockles and shrimps widely distribute among marine organisms in Thailand since they are one of the commercial sources of seafood, which may be a route of exposure to microplastics towards human. This study documents a market survey in order to understand the extension of microplastic presence in blood cockles (Anadara granosa), fine shrimp (Metapenaeus elegans) and Indian white shrimp (Fenneropenaeus indicus) sold in the fishery market in Singhanakorn district, Songkhla province. These selected species are widely consumed and economically important, especially in the southern Thailand region. The total microplastic concentration in blood cockles is $4.71 \pm 0.06 \mathrm{n} / \mathrm{g}$ (wet weight) and $2.64 \pm 0.01 \mathrm{n} /$ individual; in fine shrimp is $0.50 \pm 0.19 \mathrm{n} / \mathrm{g}$ (wet weight) and $3.70 \pm 1.12 \mathrm{n} /$ individual; in Indian white shrimp is $0.69 \pm 0.48 \mathrm{n} / \mathrm{g}$ (wet weight) and 3.45 $\pm 0.04 \mathrm{n} /$ individual. Discovered microplastics in all the species samples were mainly composed of microplastic fibres and black colour was found to be more predominant. Our results indicate that microplastic contamination is present in Thailand's commercial seafood species. As microplastic able to be transferred to human through food web, we suggest further market-based survey studies on other seafood sources.
\end{abstract}

Keywords: Cockles; contamination; microplastic; shrimps

ABSTRAK

Mikroplastik ialah salah satu punca pencemar utama dalam persekitaran marin pada abad ini. Pencemaran mikroplastik dalam ekosistem marin di wilayah Thailand telah menjadi isu persekitaran yang membimbangkan kerana ketakhadaman mikroplastik dalam hidupan laut boleh mempengaruhi keselamatan makanan laut. Kerang dan udang merupakan haiwan laut yang terkenal di Thailand sebagai salah satu punca makanan laut komersial dan mungkin boleh menjadi punca pendedahan mikroplastik kepada manusia. Kajian ini bertujuan untuk memahami pencemaran mikroplastik dalam kerang darah (Anadara granosa), udang halus (Metapenaeus elegans) dan udang putih India (Fenneropenaeus indicus) yang dijual di pasar perikanan di daearah Singhanakorn, wilayah Songkhla. Spesies ini dipilih kerana ia dimakan secara meluas oleh penduduk tempatan dan penting daripada segi ekonomi terutama di wilayah selatan Thailand. Jumlah purata bilangan mikroplastik dalam kerang darah adalah $4.71 \pm 0.06 \mathrm{n} / \mathrm{g}$ (berat basah) dan $2.64 \pm 0.01 \mathrm{n} / \mathrm{individu}$; dalam udang halus adalah $0.50 \pm 0.19 \mathrm{n} / \mathrm{g}$ (berat basah) dan $3.70 \pm 1.12 \mathrm{n} / \mathrm{individu}$; dalam udang putih India adalah $0.69 \pm 0.48 \mathrm{n} / \mathrm{g}$ (berat basah) dan $3.45 \pm 0.04 \mathrm{n} / \mathrm{individu.} \mathrm{Jumlah} \mathrm{mikroplastik} \mathrm{yang}$ paling tinggi dijumpai dalam semua sampel adalah mikroplastik yang berbentuk gentian dan mikroplastik yang berwarna hitam didapati paling banyak. Hasil kajian kami menunjukkan bahawa pencemaran mikroplastik berlaku dalam spesies makanan laut komersial di Thailand. Kami mencadangkan kajian berdasarkan tinjauan pasar perikanan dijalankan pada punca makanan laut lain kerana mikroplastik berpotensi dipindahkan kepada manusia melalui jaringan makanan.

Kata kunci: Kerang; mikroplastik; pencemaran; udang

\section{INTRODUCTION}

Regardless of the fact, plastics are very convenient in term of usage, due to the fact of their versatility in being durable, cheap, having low density and strong mechanical composition; yet plastics have become a persistent and prevalent pollutant (Wang et al. 2017). 
Microplastics (MPs) that derived from plastic debris were discovered in most of marine environment in Asia continent with secondary microplastics being recorded as the preponderance microplastic (Pradit et al. 2020; Shahul Hamid et al. 2018). China being the biggest producer of plastic waste in Asia (Rochman et al. 2015), that caused abundant availability of MPs in the coastal areas of the country which covers from China Sea towards the Bohai Sea (Yu et al. 2016). The most common types of microplastic found were expanded polystyrene (EPS) mainly discovered in coastal area of eastern and south-eastern Asia; for example, Peninsular South Korea (Kim et al. 2015) and Hong Kong (Fok \& Cheung 2015); as for most parts of Asia's marine ecosystem, polyethylene (PE) and polypropylene (PP) were majority observed. For instance, PE and PP were found in marine sediment of Singapore's coastal (Nur Hazimah \& Obbard 2014) and beaches of Peninsular Malaysia (Fauziah et al. 2015).

MPs' point of entries into the marine ecosystem originated from numerous sources such as fishery activities, wastewater, urban or industrial discharges, marine transportations, coastal and beach activities (Hossain et al. 2020; Wang et al. 2017), thus, MPs are accessible to various marine organisms. MPs were discovered in marine fishes sampled in Khark Island, Iran (Akhbarizadeh et al. 2018) and lower Gulf of Thailand (Azad et al. 2018); mussels from Bohai Sea, China (Li et al. 2016), jellyfish from South China Sea (Sun et al. 2017) and shrimps that were commercially harvested and sold in supermarkets in Singapore (Curren et al. 2020).

Among the existing MPs, microplastic fibres $(<5$ $\mathrm{mm}$ in diameter) showed highest abundance in marine environment (Mathalon \& Hill 2014). Microplastic fibres may originated from the breakdown of polymer-based textiles through either production or usage, which may derive from wastewater via domestic and industrial washing (Watts et al. 2015). These microfibres can also be the results of abrasive release from synthetic fishing gear and ropes (Malthon \& Hill 2014). MPs currently measured as a threat to the marine ecosystems because of their chemical composition, surface-volume ratio, and size, potential to adsorb and desorb toxic destructive substances (Ramirez et al. 2019). Through this context, MPs can serve as translocators of other contaminants such as persistent organic pollutants (POPs), polycyclic aromatic hydrocarbons (PAHs), trace metals and pathogenic microorganisms (Brennecke et al. 2016). Therefore, a constant interaction occurs between MPs and marine organisms continuously through various means such as ingestion, adherence, bioaccumulation, bio magnification entanglement and microbial accumulations (Avio et al. 2015).

In specific, cockles (Hermabessiere et al. 2020) and shrimps (Hossain et al. 2020) in marine food webs are able to ingest MPs through their feeding habits. Furthermore, MPs discovered to be ingested in commercial seafood sold for human consumption, which at the rate of being a potential risk for human health (Thiele et al. 2019) because cockles and shrimps are often eaten without removing their digestive tract. Studies found MP fibres in human colonic tissue samples (Ibrahim et al. 2020) and MP fragments and films in human stool samples (Schwabl et al. 2019). In addition, studies have shown that bivalves and crustaceans have the highest possibility to be exemplar for assessing the occurrence of MPs as a result of cockles possessing non-selective filter feeding that enable them to acquire the capacity to ingest and accumulate marine contaminated particles of low qualitative values such as microplastics (Mayoma et al. 2020) and shrimps having filter, suspension, and deposit-feeding strategies as well (Dawson et al. 2018). Consequently, cockles and shrimps are suitable to be good indicators based on the selection conditions that is able to reflect the grade quality status of their environment (Devriese et al. 2015). Studies investigating the benchmark degree of microplastic contamination and ingestion are still insufficient for various species, mainly commercial species and regions worldwide (Karlsson et al. 2017; Lusher et al. 2017) in particular South East Asia region.

To the best of our knowledge, this is the first research where MPs are investigated and identified in cockles and shrimps that were sold in Thailand fishery market; to be precise southern Thailand region, despite being an essential component of the marine food webs and highly consumed by local people in Thailand as a commercial source of seafood. Hence, the current study aims to determine the presence and abundance of MPs in blood cockles, Anadara granosa and selected shrimps; fine shrimp, Metapenaeus elegans and Indian white shrimp, Fenneropenaeus indicus that were sold in local fishery market. We hypothesize that these selected marine organisms integrate the occurrence of MPs and potentially provide the way of indirect MPs ingestions to human through consumption.

\section{MATERIALS AND METHODS}

STUDY SITE AND SAMPLE COLLECTION

One hundred blood cockles (A. granosa), 20 fine shrimps (M. elegans) and 20 Indian white shrimps ( $F$. indicus $)$ 
individuals were bought from the Muang Ngam fishery market located in Singhanakorn District, Songhkla Province, southern Thailand. This particular market is one of the popular seafood hubs and busiest fresh fishery markets in Songkhla Province and receiving customers, from not only Singhanakorn District but also other nearby districts such as Sathing Phra and Hat Yai Districts. Only domestic cockles and shrimps that were fresh caught from the coastal areas of the southern Gulf of
Thailand, with approximately 2 to 3 hours transportation exposure from fishermen boat to seller were purchased. As per record and acquired details of the fishery market seller, the cockles and selected shrimps were caught from coastal areas of Singhanakorn and Sathing Phra Districts as seen in the map (Figure 1). Upon complete purchase; the samples were frozen, transported and stored at $-20{ }^{\circ} \mathrm{C}$ until further laboratory analysis.

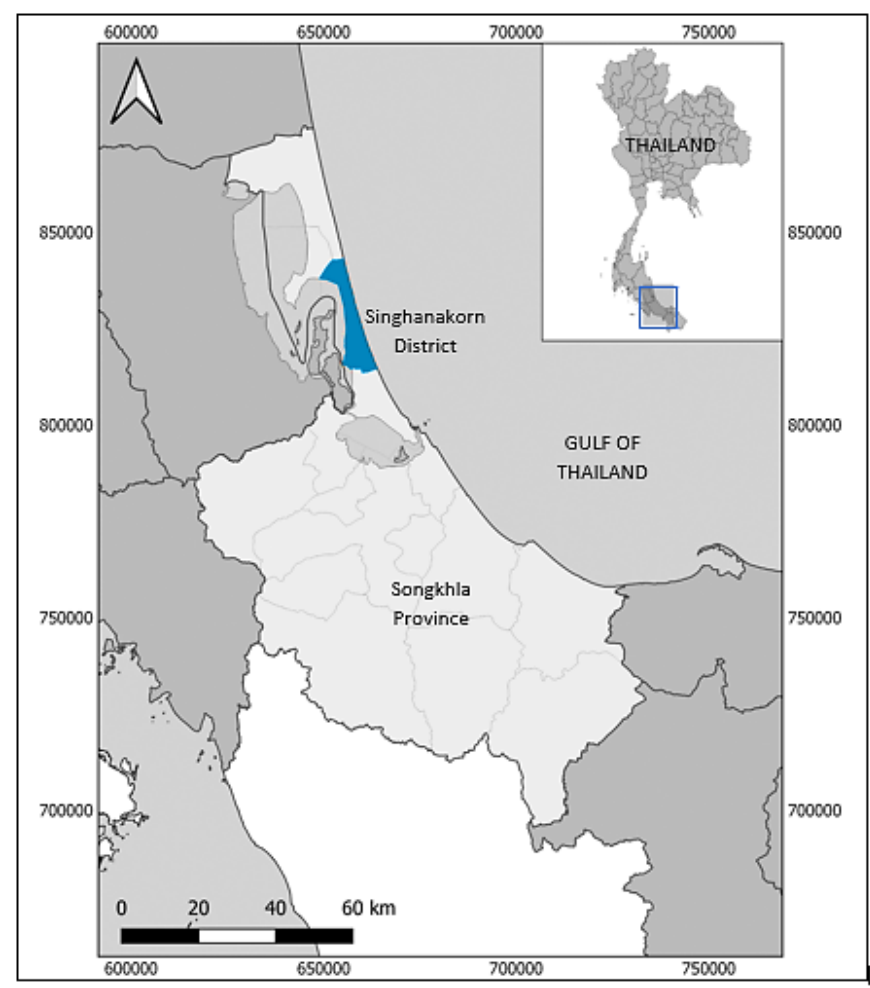

FIGURE 1. Map of study sites in Songkhla Province, lower Gulf of Thailand

\section{SAMPLE DISSECTION, DIGESTION AND MICROPLASTIC SEPARATION}

Subsequently, each selected sample was defrosted and dissected to remove the digestive tract for shrimps and the whole flesh for cockles. In order to prevent sample contamination during dissection, extraction, sorting and visual identification, specific care was applied. All the material and working surfaces were cleaned with distilled water and only cotton laboratory coats were worn during the entire laboratory analysis. As a step for background contamination prevention, an
$8 \mathrm{~cm}$ petri dish with a few $\mathrm{mL}$ of distilled water was placed next to the working zone beside the microscope to allow no atmospheric contamination detected. The amount of microplastic occurrence generated by our laboratory environment in the aforementioned blank petri dish was observed by microscope and verified by FT-IR spectrometer, the amount of the microplastic detected in each sample would be subtracted by the quantity of the microplastic from the blank to get the real amount of the microplastic present in each sample for being shown in Table 1. 
Once dissected, the wet weight of the digestive tract was recorded. Subsequently, the digestive tract samples were digested following the alkaline method describe by Cole et al. (2015) with modifications. The samples were placed in a $250 \mathrm{~mL}$ conical flask each and $150 \mathrm{~mL}$ of $10 \%$ $\mathrm{KOH}$ solution was added before sealing the flask using aluminium foil and left for 12 hours at room temperature for the assimilation process to occur. After assimilation, the conical flasks then were heated on a hotplate at $60{ }^{\circ} \mathrm{C}$ for 12 hours with 2 minutes manual shaking during every 2-hour interval, for organic matter removal process. The digested solution was then filtered immediately over a Whatman GF/F filter $0.7 \mu \mathrm{m}$ pore size using a vacuum pump without cooling down. The filters were individually placed into clean petri dishes to complete dryness in an electric thermostat blast-drying oven at 60 ${ }^{\circ} \mathrm{C}$ and then observed under dissecting microscope.

\section{MICROPLASTICS IDENTIFICATION}

Items that were identified as potential MPs were subsequently photographed. Maximum length of the MPs was measured as well as colour (black, blue, red, white, transparent) and shape (fibre, film, sphere or fragment) were noted and recorded, using a microscope Olympus SZ, lenses 110AL2X-2 with camera Canon EOS 600D. Items, which presented characteristic features of synthetic polymers, were identified as microplastics (mouldable items with consistent thickness and colour that do not break when pressed with forceps). Maximum length of the items photographed was measured using Image J 1.4.3.6 public domain program (Azad et al. 2018). Cross-validation was also carried out using Fourier Transform Infrared Spectrophotometer (FT-IR).

\section{RESULTS AND DISCUSSION}

\section{ABUNDANCE, COLOUR AND SHAPE OF MICROPLASTICS}

Microplastics were ingested in blood cockles ( $A$. granosa) sold in Singhanakorn fishery market with $100 \%$ frequency (presence in all the 100 samples). The total microplastic concentration in these blood cockles was $4.71 \pm 0.06 \mathrm{n} / \mathrm{g}$ (wet weight) and $2.64 \pm 0.01 \mathrm{n} /$ individual (Table 1). The size of microplastic particles ranged from 0.15 to $3.8 \mathrm{~mm}$. The most common size class was $0.15-0.5 \mathrm{~mm}$, and the lowest size class was $3-3.5$ mm (Figure 2). Discovered microplastics were mainly composed of fibres $(98.5 \%)$ and followed by fragments $(1.5 \%)$. There were 5 colours were detected and black $(50 \%)$ was the most common, followed by blue $(22.7 \%)$, red $(18.2 \%)$, transparent $(4.6 \%)$ and grey $(4.5 \%)$ (Figure $5)$.

Microplastics were also detected in fine shrimp ( $M$. elegans) with $100 \%$ frequency (presence in all the 20 samples). The total microplastic concentration in these shrimps were $0.50 \pm 0.19 \mathrm{n} / \mathrm{g}$ (wet weight) and $3.70 \pm 1.12$ $\mathrm{n} /$ individual (Table 1). The size of microplastic particles ranged from 0.16 to $4.1 \mathrm{~mm}$. The most common size class was $0.5-1 \mathrm{~mm}$, and the lowest size class was $3-3.5 \mathrm{~mm}$ (Figure 3). Identified microplastics were 100\% fibres with 4 colours were detected and black $(54.05 \%)$ was the most common, followed by blue $(20.72 \%)$, transparent (20.72\%), and red (1.2\%) (Figure 5).

Microplastics were also found in Indian white shrimp ( $F$. indicus) sold in Singhanakorn fishery market with $100 \%$ frequency (presence in all the 20 samples). The total microplastic concentration in these shrimps was $0.69 \pm 0.48 \mathrm{n} / \mathrm{g}$ (wet weight) and $3.45 \pm 0.04 \mathrm{n} /$ individual (Table 1). The size of microplastic particles ranged from 0.18 to $3.6 \mathrm{~mm}$. The most common size class was 0.5 $1 \mathrm{~mm}$, and the lowest size class was 2-2.5 mm (Figure 4). Discovered microplastics were $100 \%$ fibres with 4 colours were detected and black $(52.94 \%)$ was the most common, followed by blue $(27.94 \%)$, transparent (13.24\%), and red (5.88\%) (Figure 5).

\section{TYPE OF PLASTIC}

The type of plastic found in blood cockles (A. granosa), fine shrimp ( $M$. elegans) and Indian white shrimp ( $F$. indicus) sold in the fishery market in Singhanakorn District, Songkhla Province was polyethylene (PE). PE is widely used in many applications such as food packages and containers. From FT-IR spectrum obtained from our study in Figure 6, polymer type polyethylene (PE) detected using FT-IR in representative samples for blood cockles $A$. granosa (A), fine shrimps M. elegans (B) and Indian white shrimp F. indicus (C).

From the FT-IR spectra in Figure 6, it clearly shows the absorption band of PE characteristics. The absorption peaks around $2800-2900 \mathrm{~cm}^{-1}$ are referred to symmetric and asymmetric $\mathrm{C}-\mathrm{H}$ stretching. The strong absorption band at $1470 \mathrm{~cm}^{-1}$ is due to $\mathrm{C}-\mathrm{H}$ deformation in the $\mathrm{PE}$ structure (Asgari et al. 2014; Lefakane et al. 2015). These are proven that PE is observed in all samples. The absorption peaks at $1600-1700 \mathrm{~cm}^{-1}$ referred to $\mathrm{C}=\mathrm{C}$ and $\mathrm{C}=\mathrm{O}$ vibrations are observed in all FTIR spectra. Considering the PE structure, it is not contained of those $\mathrm{C}=\mathrm{C}$ and $\mathrm{C}=\mathrm{O}$ bonds. The presence of those absorption peaks might be affected by the degradation of PE or other 
additives. Moreover, the vibration band at about 1000 $\mathrm{cm}^{-1}$ is strongly present in all results. Generally, it is due to the vibration of $\mathrm{Si}-\mathrm{O}-\mathrm{Si}$ structure. This is possible that the presence of some chemicals with $\mathrm{Si}-\mathrm{O}-\mathrm{Si}$ bonds in their structures or even some contamination (Lin \& Wang 2014).

TABLE 1. Total concentration and abundance of microplastics in blood cockles (A. granosa), fine shrimp (M. elegans) and Indian white shrimp (F. indicus)

\begin{tabular}{|c|c|c|c|}
\hline Category & A. granosa & M. elegans & F. indicus \\
\hline No. of individuals & 100 & 20 & 20 \\
\hline Mean wet weight (g) & $2.24 \pm 1.32$ (without shell) & $7.53 \pm 1.12$ & $5.03 \pm 0.42$ \\
\hline Mean length $(\mathrm{cm})$ & $3.46 \pm 0.21$ & $8.02 \pm 0.03$ & $7.08 \pm 1.05$ \\
\hline Total no. of microplastics & 264 items & \multirow{3}{*}{$\begin{array}{l}76 \text { items } \\
100\end{array}$} & \multirow{3}{*}{$\begin{array}{l}66 \text { items } \\
100\end{array}$} \\
\hline Microplastics frequency (\%) & 100 & & \\
\hline Microplastics shape (\%): & & & \\
\hline Fibre & 98.5 & \multirow{2}{*}{100} & \multirow{2}{*}{100} \\
\hline Fragment & 1.5 & & \\
\hline \multicolumn{4}{|l|}{ Microplastics Concentration: } \\
\hline $\mathrm{n} / \mathrm{g}$ wet weight & $4.71 \pm 0.06$ & $0.50 \pm 0.19$ & $0.69 \pm 0.48$ \\
\hline $\mathrm{n} /$ individual & $2.64 \pm 0.01$ & $3.80 \pm 1.12$ & $3.31 \pm 0.04$ \\
\hline
\end{tabular}

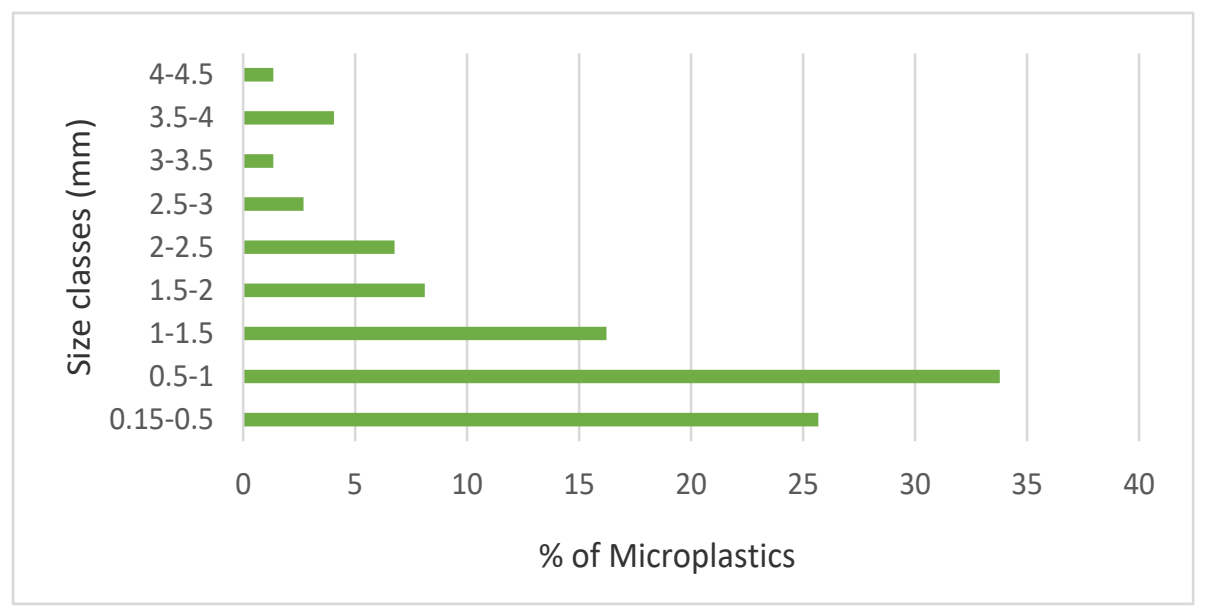

FIGURE 2. Percentage of microplastics in blood cockles (A. granosa) according to their size classes 


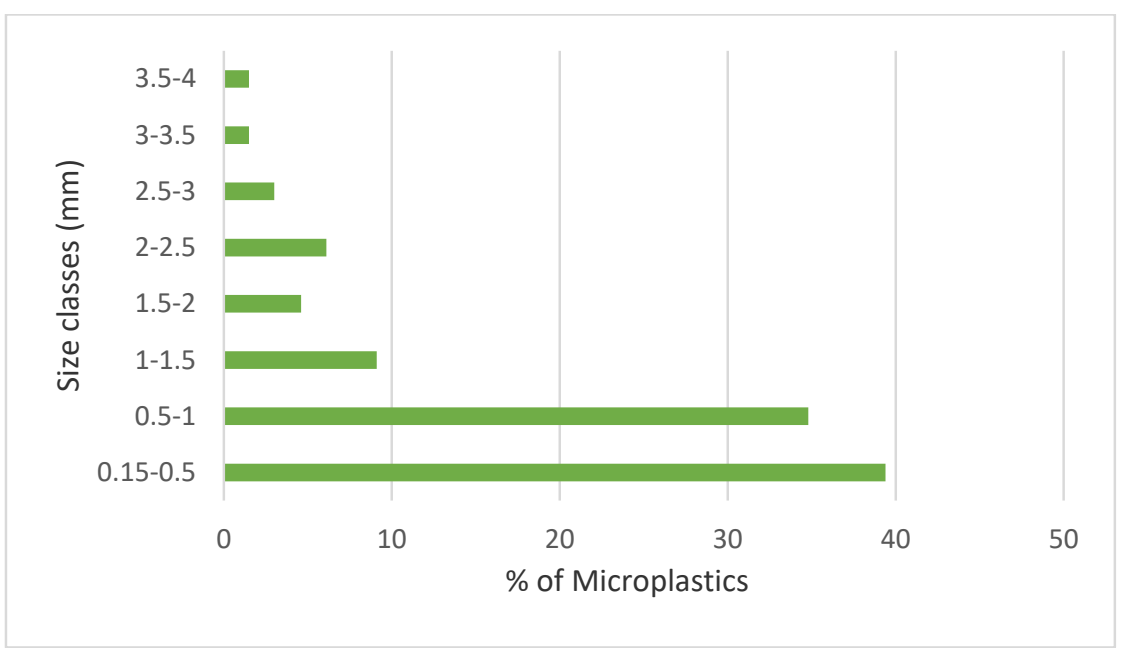

FIGURE 3. Percentage of microplastics in fine shrimps (M. elegans) according to their size classes

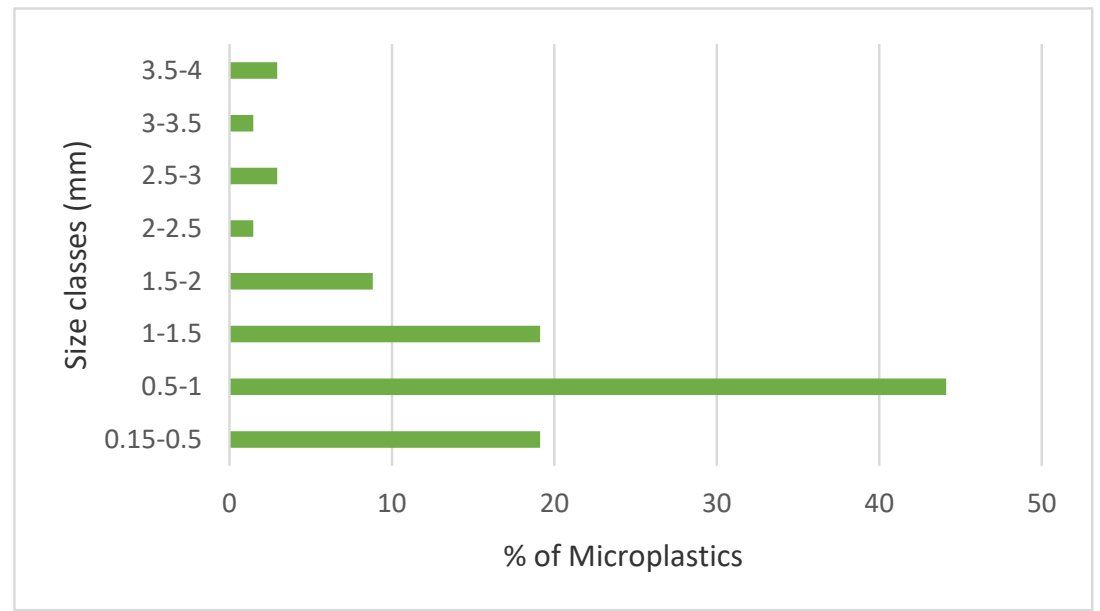

FIGURE 4. Percentage of microplastics in Indian white shrimps ( $F$. indicus) according to their size classes

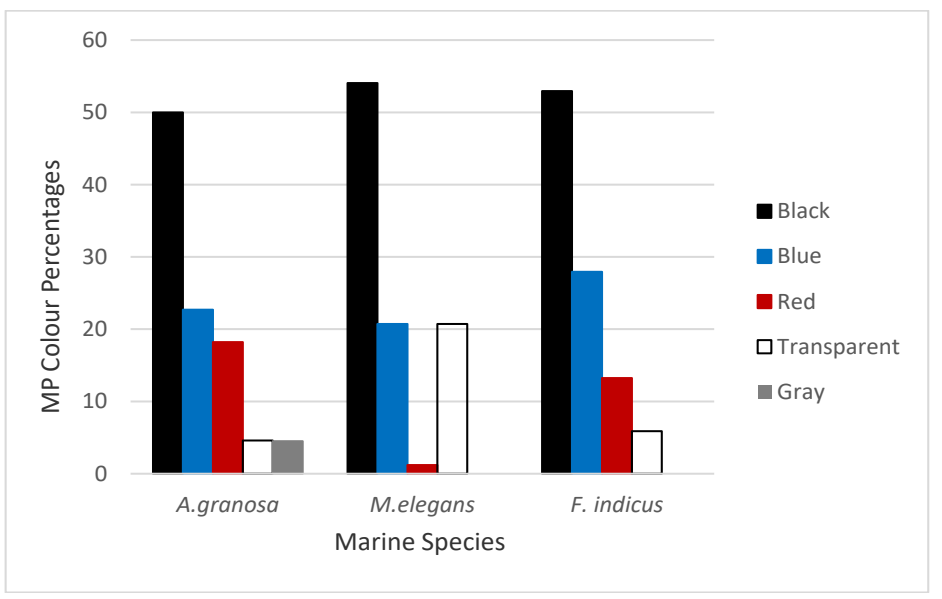

FIGURE 5. Microplastic colours detected in blood cockles (A. granosa), fine shrimps (M. elegans) and Indian white shrimps (F. indicus) and their relative frequencies 

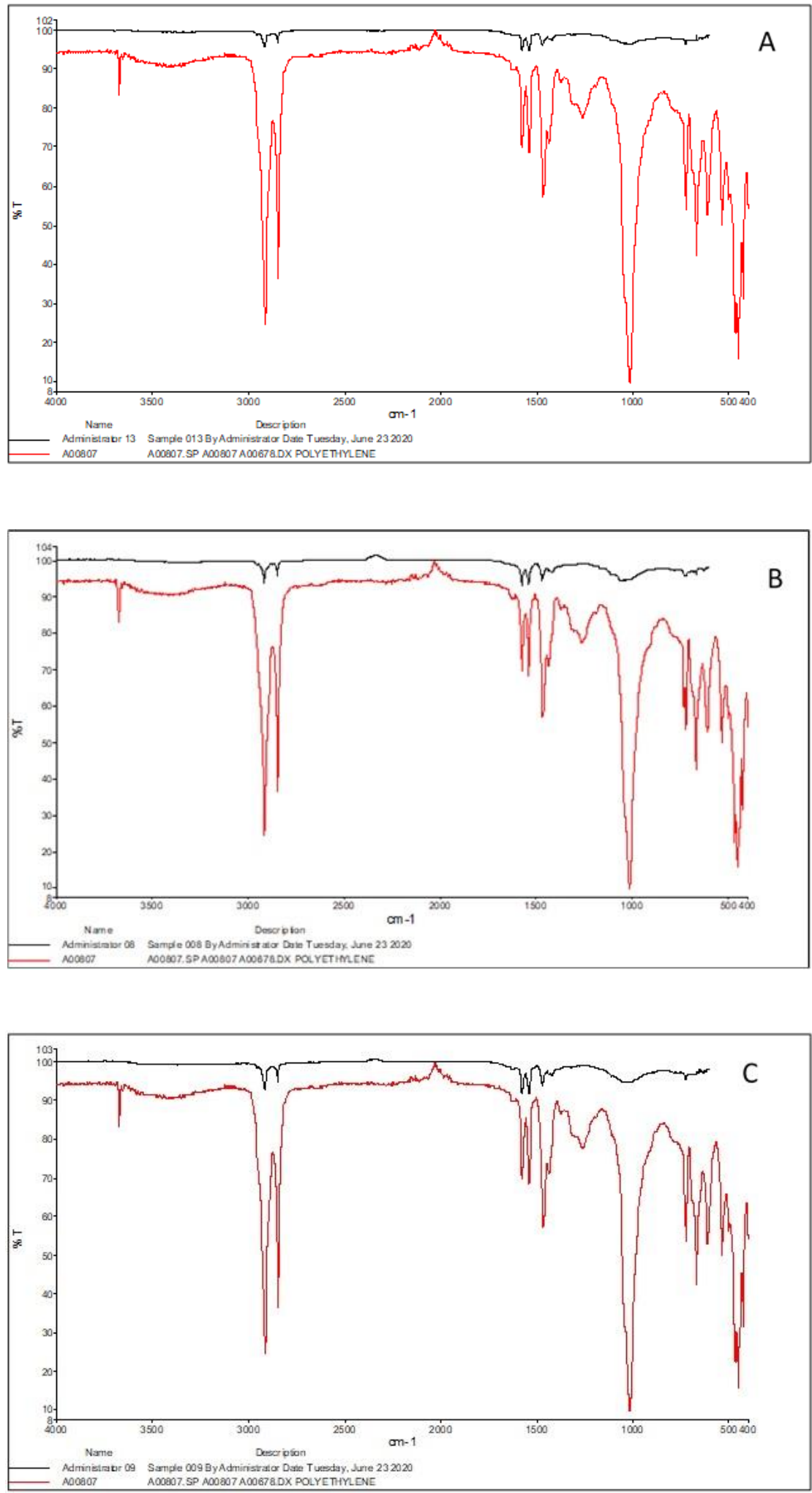

FIGURE 6. Microplastic polymer type of polyethylene (PE) detected by using FTIR in representative samples for blood cockles (A. granosa) (A), fine shrimps ( $M$. elegans) (B) and Indian white shrimp (F. indicus) $(\mathrm{C})$ 
Microplastics were detected in all of the marine species samples that were sold in Singhanakorn fishery market (Figure 7). This result indicates that MPs contamination in market cockles and shrimps may be related to the place they originated. According to the information acquirement from the sellers, both cockles and shrimps were caught near the coastal areas of Singhanakorn and Sathing Phra Districts. Previous studies observed that ingestion of MPs in bivalves reflected in terms of number, shape and size in the surrounding waters (Cho et al. 2019; Qu et al. 2018). The MPs levels shown in this study were compared with those in cockles and shrimps reported worldwide based on the availability of studies done. The concentration of MPs in blood cockles $A$. granosa in this research (Table 2 ) is relatively low as compared to the same species of cockles from Jambi (Fitri \& Patria 2019) and Semarang (Suprayogi \& Ivana 2018), Indonesia. The comparison is different and has a gap in both MPs concentrations per individual, and per wet weight of sample, although Thailand and Indonesia are located in the South East Asia region. This situation may be the consequence of the different MPs contamination levels in the cockles' habitat or environment. In addition, the levels of MPs may vary in different types of cockle species and the location they came from as seen in Table 2. The MPs concentration in $C$. edale from the coastal area of France (Hermabessiere et al. 2019) and A. antiquata from the coastal areas of Tanzania are slightly lower as compared to MPs ingested by $A$. granosa in this study.

The difference of MPs concentrations (n/g w.w) in shrimp samples (M. elegans) and (F. indicus) in this study is lower than MPs in P. muelleri from Argentina (Severini et al. 2020) and A. antennatus from Spain (Carreras-Colom et al. 2018). This contrast may relate to the shrimp size itself, as A. antennatus is bigger than the other species shown in Table 2. MPs concentrations in shrimps in this research are slightly higher in comparison with MPs in brown shrimp (C. crangon) observed in the study of Southern North Sea, Europe (Devriese et al. 2015).

The variation of MPs concentration of these marine species is strongly associated with the difference of regional MPs contamination status and affected by analytical methods. Throughout the process of finding the most suitable digestion method for MPs analysis, numerous studies applied different methods for sample treatment and MPs identification; whereby chemical reagents for digestion were assorted such $\mathrm{H}_{2} \mathrm{O}_{2}, \mathrm{HNO}_{3}$, $\mathrm{HCl}$, enzyme, or $\mathrm{KOH}$ and the application of density separation using $\mathrm{NaCl}$, LMT or KI. Moreover, the usage of different pore size filter papers and identification methods either visual or chemical may vastly influence the results for MPs analysation (Cho et al. 2019; Renzi et al. 2018). Notably for market samples, the difference may also be due to depuration of particles during transportation and storage. In a study, the researchers showed that MPs concentrations decreased by almost $30 \%$ in mussels and oysters after 3 days of depuration (Van Cauwenberghe \& Janssen 2014).

Based on the results, fibres were found to be more predominant in the samples and it is very common to find in MPs researches. Studies suggested that microfibres have taken up to $91 \%$ of the entire plastics collected in global seawater samples and microfibres were the most ubiquitous in ocean surface waters (Barrows et al. 2018). Fibres usually appear to be yarn or threadlike either found in crumpled or single linen and considered as degradable plastic waste (Pirc et al. 2016). Commonly fibres originated from fishing nets, ropes, lines, laundry, and urban wastes (Hossain et al. 2020; Severini et al. 2020). The cockle and shrimp samples in this study were caught near the coastal areas of Singhanakorn and Sathing Phra Districts which, are known for fishery industries and activities. In accordance, the microfibres found in the samples may come from fishing nets, lines or ropes.

The FT-IR results showing the representative microplastic samples detected identified as polyethylene (PE). In polymer context and composition, $\mathrm{PE}$ is the main material extensively used for the fabrication of HDPE ropes and fishing nets. Ropes are widely used in fishing activities and docking of ships in marine related industries (Jang et al. 2014). The contamination of microplastic fibres occurs when these manufactured ropes become worn out and resulting on irresponsible discards which eventually end up in the seawater or the marine sediments, affecting the organisms that inhabit them.

One of the main factors that determines the food compositions of these selected marine samples of this study is their feeding strategies. Blood cockles (A. granosa) similar to other species of bivalves like mussels or oysters have filter-feeding strategy. This particular feeding way allows cockles to take up everything in their surrounding waters with risk of microplastics being ingested together with their source of food such as copepods, decapods and other types of planktons (Mayoma et al. 2020). On the other hand, shrimps are mainly found near the seafloor of coastal area. In despite being less in individual number (20), they ingested quite a high amount of microplastics. 
TABLE 2. Microplastics in cockles and shrimps

\begin{tabular}{|c|c|c|c|c|c|}
\hline Cockles & & & & & \\
\hline Location & Species & MPs Abundance & MPs shape type & MPs size range & References \\
\hline France & $\begin{array}{l}\text { Cerastoderma } \\
\text { edale }\end{array}$ & $\begin{array}{c}0.74 \pm 0.35 \mathrm{n} / \mathrm{g} \text { w.w } \\
2.46 \pm 1.16 \mathrm{n} / \text { individual }\end{array}$ & $\begin{array}{l}\text { Fibres, } \\
\text { fragments, } \\
\text { films }\end{array}$ & - & $\begin{array}{l}\text { Hermabessiere et } \\
\text { al. (2019) }\end{array}$ \\
\hline $\begin{array}{l}\text { Jambi, } \\
\text { Indonesia }\end{array}$ & Anadara granosa & $\begin{array}{c}4.1 \pm 0.43 \mathrm{n} / \mathrm{g} \text { w.w } \\
180.6 \pm 21.22 \mathrm{n} / \text { individual }\end{array}$ & Fibres & - & $\begin{array}{l}\text { Fitri \& Patria } \\
\qquad(2019)\end{array}$ \\
\hline $\begin{array}{l}\text { Semarang, } \\
\text { Indonesia }\end{array}$ & Anadara granosa & $23.17 \pm 13.02 \mathrm{n} /$ individual & $\begin{array}{l}\text { Fibres, films, } \\
\text { pellets, foam }\end{array}$ & $0.02-0.05 \mathrm{~mm}$ & $\begin{array}{l}\text { Suprayogi \& } \\
\text { Ivana (2018) }\end{array}$ \\
\hline Tanzania & Anadara antiquata & $2.1 \pm 1.8 \mathrm{n} /$ individual & $\begin{array}{l}\text { Fibres, } \\
\text { fragments }\end{array}$ & - & $\begin{array}{l}\text { Mayoma et al. } \\
\qquad(2020)\end{array}$ \\
\hline $\begin{array}{l}\text { Songkhla, } \\
\text { Thailand }\end{array}$ & Anadara granosa & $\begin{array}{c}4.71 \pm 0.06 \mathrm{n} / \mathrm{g} \text { w.w } \\
2.64 \pm 0.01 \mathrm{n} / \text { individual }\end{array}$ & $\begin{array}{l}\text { Fibres, } \\
\text { fragments }\end{array}$ & $0.15-3.8 \mathrm{~mm}$ & This study \\
\hline \multicolumn{6}{|l|}{ Shrimps } \\
\hline $\begin{array}{l}\text { Canal Vieja, } \\
\text { Argentina }\end{array}$ & Pleoticus muelleri & $1.43 \pm 0.90 \mathrm{n} / \mathrm{g} \mathrm{w} . \mathrm{w}$ & Fibres & $0.14-2.36 \mathrm{~mm}$ & $\begin{array}{l}\text { Severini et al. } \\
\qquad(2020)\end{array}$ \\
\hline $\begin{array}{c}\text { Southern } \\
\text { North Sea \& } \\
\text { Chanel Area, } \\
\text { Europe }\end{array}$ & Crangon crangon & $\begin{array}{c}0.68 \pm 0.55 \mathrm{n} / \mathrm{g} \text { w.w } \\
1.23 \pm 0.99 \mathrm{n} / \text { individual }\end{array}$ & Fibres & $0.2-1 \mathrm{~mm}$ & Devriese (2015) \\
\hline $\begin{array}{l}\text { Barcelona, } \\
\text { Spain }\end{array}$ & $\begin{array}{l}\text { Aristeus } \\
\text { antennatus }\end{array}$ & $14.29 \pm 1.58 \mathrm{n} / \mathrm{g} \mathrm{w} . \mathrm{w}$ & Fibres & $\begin{array}{c}1.9-26.7 \\
\text { mm (range } \\
\text { of plastic } \\
\text { particles) }\end{array}$ & $\begin{array}{l}\text { Carreras-Colom } \\
\text { et al. (2018) }\end{array}$ \\
\hline $\begin{array}{l}\text { Songkhla, } \\
\text { Thailand }\end{array}$ & $\begin{array}{l}\text { Metapenaeus } \\
\text { elegans }\end{array}$ & $\begin{array}{c}0.50 \pm 0.19 \mathrm{n} / \mathrm{g} \text { w.w } \\
3.80 \pm 1.12 \mathrm{n} / \text { individual }\end{array}$ & Fibres & $0.16-4.1 \mathrm{~mm}$ & This study \\
\hline $\begin{array}{l}\text { Songkhla, } \\
\text { Thailand }\end{array}$ & $\begin{array}{c}\text { Fenneropenaeus } \\
\text { indicus }\end{array}$ & $\begin{array}{c}0.69 \pm 0.48 \mathrm{n} / \mathrm{g} \text { w.w } \\
3.31 \pm 0.04 \mathrm{n} / \text { individual }\end{array}$ & Fibres & $0.18-3.6 \mathrm{~mm}$ & This study \\
\hline
\end{tabular}

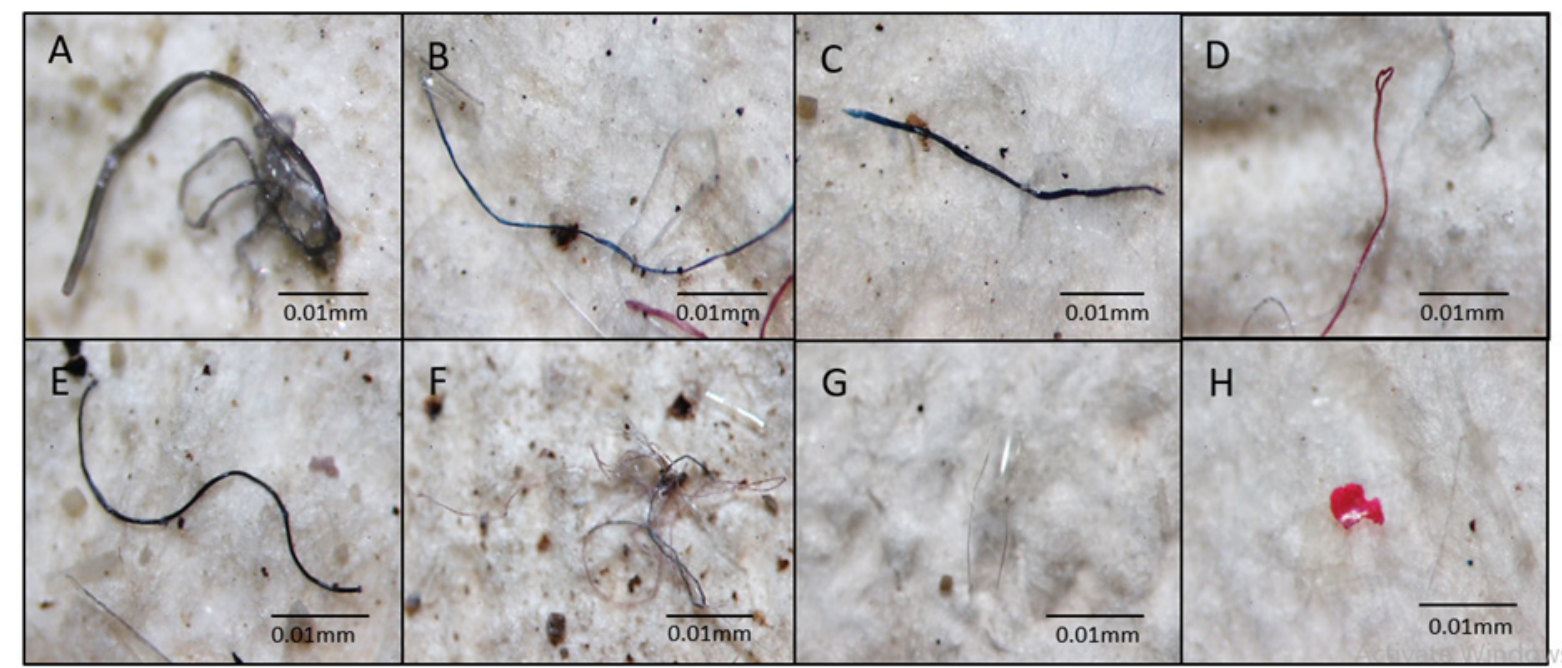

FIGURE 7. Examples of microplastics fibres found in blood cockles (A. granosa) (A,B), fine shrimps (M. elegans) (C,D), Indian white shrimp (F. indicus) $(\mathrm{E}, \mathrm{F})$ and microplastic fragments found in blood cockles $($ A. granosa $)(\mathrm{G}, \mathrm{H})$ 
Shrimp samples in this study are omnivorous feeder, opportunistic feeders, using their setose (bristly) legs as a sieve; some scrapes algae from rocks (Dawson et al. 2018). These shrimps when scraping for food they might as well mistakenly feed on microplastic particles (most likely fibrous) that resemble algae. As a source of seafood, shrimps are still at safe a level to eat with the condition of removing their heads and stomachs as well.

The negative reflection of microplastic ingestions by marine organisms can be observed at behavioural and physiological aspects. Multiple studies have investigated the adverse health effects caused by microplastics uptake in marine organisms that include decreased growth rate, weight loss, decreased food consumption and increased immune system responses (Lusher et al. 2017; Rochman et al. 2015), reverse effects on respiratory and reproduction system (Avio et al. 2015; Cole et al. 2015). As it is known that blood cockles have not only similar feeding strategy as other bivalves but also share related digestive system, growth, and habitat (Mayoma et al. 2020). It is empirical to understand the levels of microplatic ingestion effects that might disturb the cockles' health, physiology and behaviour. A study compares the toxicity of microplastics (20 $\mu \mathrm{m}$ polystyrene), microfibres ( $30 \mu \mathrm{m}$ polyamide) and nanoplastics (50 nm polystyrene) in mussels (Mytilus spp.) and found that the amounts of microplastics and microfiber particles increased in the mussels' digestive gland within 7 days after exposure (Cole et al. 2020). The study also discovered that nanoplastics induced the level of mussels' immune system because of significant effect on hyalinocytegranulocyte. This finding highlighted that plastic particulate toxicity in marine organisms strongly related to particle size factor. Another study by Green (2016), explored the effects of conventional and biodegradable microplastics; high-density polyethylene (HDPE) and polylactic acid (PLA) in European flat oyster (Ostrea edilus L.). This researcher discovered that exposure to high concentrations of PLA after 60 days caused the oysters' respiration rates raised up suggesting the occurrence of stress induced. In another laboratory study, the constant ingestion and the accumulation of microplastics in the bivalves could result in chronic effects. Avio et al. (2015) confirmed that mussel Mytilus edilus possessed the capability to ingest and accumulate both virgin and contaminated microplastics. The authors observed that the concentration of pyrene increased in mussels' digestive gland through exposure to microplastics and pyrene treatments in comparison with mussels treated with only pyrene. This report reflected the evidence of microplastics' capacity to act as pollutant vehicles. In addition, high concentrations of pyrene in mussels induced several effects at cellular level such as oxidative stress and genotoxicity at transcriptional level such as down regulation of citrate cycle and arachidonic acid metabolism (Avio et al. 2015).

The results of shrimps being able to ingest and retain microplastics elevated the risk of these organisms that were susceptible to adverse effects. Gray and Weinstein (2017) characterized the size and shape dependent effects of microplastics particles; sphere, fibres and fragments on adult grass shrimp (Palaemonetes pugio). The authors found that microplastic spheres and fragments $<50 \mu \mathrm{m}$ were not acutely toxic, but the toxicity rate increased up to $40 \%$ of particles size $>50$ $\mu \mathrm{m}$. Moreover, the study showed that the most significant mortality in shrimps ingested $93 \mu \mathrm{m}$ fibres. Another study evaluated the impact of microplastics ingestion on the susceptibility of the same species grass shrimp $(P$. pugio) to bacterial infection with Vibrio campelli. The grass shrimps were exposed to treatments containing natural sediment, polyethylene spheres, polypropylene fragments, tyre fragments, and polyester fibres (Leads et al. 2019). The authors found that the shrimps ingested all the particles but no significant mortality prior to the bacteria challenge. However, the study emphasized on more understanding of the size and shape dependent effects of microplastics ingestion in shrimps as most fibrous particles were detected in guts and gills. Another study documented the ingestion effects of 4 different sizes (1, 3,6 , and $10 \mu \mathrm{m}$ ) non-functional polystyrene microbeads in brine shrimp (Artemia franciscana) (Jin et al. 2020). A. franciscana clearly showed ingestion and egestion of the microbeads with significant inhibitory effect on AChE activity eventually increases mortality within 30 days. The study suggested that microplastics exposure to the early stages of brine shrimp could be harmful to population conservation as the adverse effect of cholinergic system inhibition and induction of acute cell stress.

\section{CONCLUSION}

Blood cockles $A$. granosa, fine shrimp $M$. elegans and Indian white shrimp $F$. indicus from Singhanakorn fishery market, Songkhla, Thailand sold for human consumption been proven contaminated with the abundant number of microplastics. This is the first study to assess the level of microplastic contamination and occurrence in commercial blood cockles and shrimps in Thailand. The fibrous microplastic type was the most predominance and only polyethylene (PE) polymer type was identified. The ingestion of microplastics in these selected seafood species indicates that there is a potential of microplastic transfer to human consumers. 


\section{ACKNOWLEDGEMENTS}

This work was supported and made possible by financial support from Thailand Education Hub for ASEAN countries scholarship (TEH-AC), Graduate School, Prince of Songkla University and Coastal Oceanography and Climate Change Research Centre (COCC), Prince of Songkla University.

\section{REFERENCES}

Akhbarizadeh, R., Moore, F. \& Keshavarzi, B. 2018. Investigating a probable relationship between microplastics and potentially toxic elements in fish muscles from northeast of Persian Gulf. Environmental Pollution 232: 154-163.

Asgari, P., Moradi, O. \& Tajeddin, B. 2014. The effect of nanocomposite packaging carbon nanotube base on organoleptic and fungal growth of Mazafati brand date. International Nano Letters 4(98): 1-5.

Avio, C.G., Gorbi, S., Milan, M., Benedetti, M., Fattorini, D., d'Errico, G., Pauletto, M., Bargelloni, L. \& Regoli, F. 2015. Pollutants bioavailability and toxicological risk from microplastics to mussels. Environment Pollution 198: 211-222.

Azad, S.M.O., Towatana, P., Pradit, S., Patricia, B.G., Hue, H.T.T. \& Jualaong, S. 2018. First evidence of existence of microplastics in stomach of commercial fishes in the Lower Gulf of Thailand. Applied Ecology and Environmental Research 16(6): 7345-7360.

Barrows, A.P.W., Cathey, S.E. \& Petersen, C.W. 2018. Marine environment microfiber contamination: global patterns and the diversity of microparticle origins. Environmental Pollution 237: 275-284.

Brennecke, D., Bernardo, D., Filipa, P. \& Isabel, C. 2016. Microplastics as vector for heavy metal contamination from the marine environment. Estuarine, Coastal and Shelf Science 178: 189-195.

Carreras-colom, E., Constenla, M., Soler-membrives, A., Cartes, J.E. \& Baeza, M. 2018. Spatial occurrence and effects of microplastic ingestion on the deep-water shrimp Aristeus antennatus. Marine Pollution Bulletin 133: 44-52.

Cho, Y., Won, J.S., Mi, J., Gi, M.H. \& Sang, H.H. 2019. Abundance and characteristics of microplastics in market bivalves from South Korea. Environmental Pollution 245: 1107-1116.

Cole, M., Liddle, C., Consolandi, G., Drago, C., Hird, C., Lindeque, P.K. \& Galloway, T.S. 2020. Microplastics, microfibres and nanoplastics cause variable sub-lethal responses in mussels (Mytilus spp.). Marine Pollution Bulletin 160: 111552.

Cole, M., Lindeque, P., Fileman, E., Halsband, C. \& Galloway, T. 2015. The impact of polystyrene microplastics on feeding, function and fecundity in the marine copepod Calanus helgolandicus. Environmental Science \& Technology 49: 1130-1137.
Curren, E., Leaw, C.P., Lim, P.T. \& Leong, S.C.Y. 2020. Evidence of marine microplastics in commercially harvested seafood. Frontiers in Bioengineering \& Biotechnology 8: 562760 .

Dawson, A.L., Kawaguchi, S. \& King, C.K. 2018. Turning microplastics into nanoplastics through digestive fragmentation by Antarctic krill. Nature Communications 9: $1-8$.

Devriese, L.I., Van Der Meulen, M.D., Maes, T., Bekaert, K., Paul-pont, I., Frère, L., Robbens, J. \& Vethaak, A.D. 2015. microplastic contamination in brown shrimp (Crangon crangon, Linnaeus 1758) from coastal waters of the Southern North Sea and channel area. Marine Pollution Bulletin 98(1-2): 179-187.

Fauziah, S.H., Liyana, I.A. \& Agamuthu, P. 2015. Plastic debris in the coastal environment: The invincible threat? Abundance of buried plastic debris on Malaysian beaches. Waste Management and Research 33: 812-821.

Fitri, S. \& Patria, M.P. 2018. Microplastic contamination on Anadara granosa Linnaeus 1758 in Pangkal Babu Mangrove forest area, Tanjung Jabung Barat district, Jambi. Journal of Physics: Conference Series 1282: 012109.

Fok, L. \& Cheung, P.K. 2015. Hong Kong at the Pearl River Estuary: A hotspot of microplastic pollution. Marine Pollution Bulletin 99: 112-118.

Gray, A.D. \& Weinstein, J.E. 2017. Size and shape-dependent effects of microplastic particles on adult dagger blade grass shrimp (Palaemonetes pugio). Environmental Toxicology and Chemistry 36(11): 3074-3080.

Green, D.S. 2016. Effects of microplastics on European flat oysters, Ostrea edulis and their associated benthic communities. Environment Pollution 216: 95-103.

Hermabessiere, L., Paul-Pont, I., Cassone, A.L., Himber, C., Receveur, J., Jezequel, R., El Rakwe, M., Rinnert, E., Gilles, R., Lambert, C., Huvet, A., Dehaut, A., Duflos, G. \& Soudant, P. 2019. Microplastic contamination and pollutant levels in mussels and cockles collected along the channel coasts. Environmental Pollution 250: 807-819.

Hossain, M.S., Rahman, M.S. \& Uddin, M.N. 2020. Microplastic contamination in Penaeid shrimp from the Northern Bay of Bengal. Chemosphere 238: 124688 124697.

Ibrahim, Y.S., Dzulkarnaen, A., Zakaria, Z., Mustaffa, N., Sharif, S.E.T. \& Yeong, Y.L. 2020. Detection of microplastics in human colectomy specimens. JGH Open 5(1): 116-121.

Jang, Y.C., Lee, J. \& Hong, S. 2014. Sources of plastic marine debris on beaches of Korea: More from the ocean than the land. Ocean Science Journal 49: 151-162.

Jin, H.E., Sang, E.N. \& Jae, S.R. 2020. Polystyrene microplastics induce mortality through acute cell stress and inhibition of cholinergic activity in a brine shrimp. Molecular \& Cellular Toxicology 16(3): 233-243.

Karlsson, T.M., Vethaak, A.D., Carney, B., Ariese, F., Velzen, M.V., Hassellöv, M. \& Leslie, H.A. 2017. Screening for microplastics in sediment, water, marine invertebrates and 
fish: Method development and microplastic accumulation. Marine Pollution Bulletin 122(1-2): 403-408.

Kim, I.S., Chae, D.H. \& Kim, S.K. 2015. Factors influencing the spatial variation of microplastics on high-tidal coastal beaches in Korea. Archives of Environmental Contamination and Toxicology 69: 299-309.

Leads, R.R., Burnett, K.G. \& Weinstein, J.E. 2019. The effect of microplastic ingestion on survival of the grass shrimp Palaemonetes pugio (Holthuis, 1949) challenged with Vibrio campbellii. Environmental Toxicology and Chemistry 38(10): 2233-2242.

Lefakane, T.E., Ndibewu, P.P. \& Netshiozwi, T.E. 2015. Characterization, chemical phase indentification, and performance evaluation of omnipotent polymers used in the manufacturing of personal protective garments. Polymers Research Journal 9(4): 407-425.

Li, J., Qu, X. \& Su, L. 2016. Microplastics in mussels along the coastal waters of China. Environmental Pollution 214: 177-184.

Lin, J.Y. \& Wang, B.X. 2014. Room-temperature voltage stressing effects on resistive switching of conductivebridging RAM cells with $\mathrm{Cu}$-doped $\mathrm{SiO} 2$ films. Advances in Materials Science and Engineering 2014: Article ID. 594516.

Lusher, A.L., Welden, N.A., Sobral, P. \& Cole, M. 2017. Sampling, isolating and identifying microplastics ingested by fish and invertebrates. Analytical Methods 9(9): 13461360.

Mathalon, A. \& Hill, P. 2014. Microplastic fibers in the intertidal ecosystem surrounding Halifax Harbor, Nova Scotia. Marine Pollution Bulletin 81(1): 69-79.

Mayoma, B.S., Sørensen, C., Shashoua, Y. \& Khan, F.R. 2020. Microplastics in beach sediments and cockles (Anadara antiquata) along the Tanzanian coastline. Bulletin of Environmental Contamination and Toxicology 105(4): 513-521.

Nur Hazimah, M.N. \& Obbard, J.P. 2014. Microplastics in Singapore's coastal mangrove ecosystems. Marine Pollution Bulletin 79: 278-283.

Pirc, U., Vidmar, M., Mozer, A. \& Krzan, A. 2016. Emissions of microplastic fibers from microfiber fleece during domestic washing. Environmental Science Pollution Research 23(21): 22206-222111.

Pradit, S., Towatana, P., Nitiratsuwan, T., Darakai, Y. \& Weerawong, C. 2020. Occurrence of microplastics on beach sediment at Libong, a pristine island in Andaman Sea, Thailand. ScienceAsia 46(3): 336-343.

Qu, X., Su, L., Li, H., Liang, M. \& Shi, H. 2018. Assessing the relationship between the abundance and properties of microplastics in water and in mussels. Science of The Total Environment 621: 679-686.

Ramirez, M.M.B., Caamal, R.D. \& von Osten, J.R. 2019. Occurrence and seasonal distribution of microplastics and phthalates in sediments from the urban channel of the Ria and coast of Campeche, Mexico. Science of The Total Environment 672: 97-105.
Renzi, M., Guerranti, G. \& Blaŝković, A. 2018. Microplastic contents from maricultured and natural mussels. Marine Pollution Bulletin 131: 248-251.

Rochman, C.M., Tahir, A. \& Williams, S.L. 2015. Anthropogenic debris in seafood: Plastic debris and fibers from textiles in fish and bivalves sold for human consumption. Scientific Reports 5: 1-10.

Schwabl, P., Köppel, S. \& Königshofer, P. 2019. Detection of various microplastics in human stool: A prospective case series. Annals of Internal Medicine 171: 453-457.

Severini, M.D.F., Buzzi, N.S., López, A.D.F., Colombo, C.V., Sartor, G.L.C., Rimondino, G.N. \& Truchet, D.M. 2020. Chemical composition and abundance of microplastics in the muscle of commercial shrimp Pleoticus muelleri at an impacted coastal environment (Southwestern Atlantic). Marine Pollution Bulletin 161: 111700.

Shahul Hamid, F., Bhatti, M.S., Anuar, N., Mohan, P. \& Periathamby, A. 2018. Worldwide distribution and abundance of microplastic: How dire is the situation? Waste Management \& Research 36(10): 873-897.

Sun, X., Li, Q. \& Zhu, M. 2017. Ingestion of microplastics by natural zooplankton groups in the northern South China Sea. Marine Pollution Bulletin 115: 217-224.

Thiele, C.J., Hudson, M.D. \& Russell, A.E. 2019. Evaluation of existing methods to extract microplastics from bivalve tissue: Adapted $\mathrm{KOH}$ digestion protocol improves filtration at single-digit pore. Marine Pollution Bulletin 142: 384-393.

Van Cauwenberghe, L. \& Janssen, C.R. 2014. Microplastics in bivalves cultured for human consumption. Environmental Pollution 193: 65-70.

Wang, J., Peng, J., Tan, Z., Gao, Y., Zhan, Z. \& Chen, Q. 2017. Chemosphere microplastics in the surface sediments from the Beijing river littoral zone: Composition, abundance, surface textures and interaction with heavy metals. Chemosphere 171: 248-258.

Watts, A.J.R., Urbina, M.A., Corr, S., Lewis, C. \& Galloway, T.S. 2015. Ingestion of plastic microfibers by the crab Carcinus maenas and its effect on food consumption and energy balance. Environmental Science \& Technology 49(24): 14597-14604.

Yu, X., Peng, J. \& Wang, J. 2016. Occurrence of microplastics in the beach sand of the Chinese inner sea: The Bohai Sea. Environmental Pollution 214: 722-730.

Patricia Blair Goh, Siriporn Pradit*, Prawit Towatana \& Butchanok Kongket

Marine and Coastal Resources Institute

Faculty of Environmental Management

Prince of Songkla University

Songkhla 90110

Thailand 
Patricia Blair Goh, Siriporn Pradit* \& Prawit Towatana Coastal Oceanography and Climate Change Research Center Prince of Songkla University

Songkhla 90110

Thailand

Somkiat Khokkiatiwong

Department of Marine and Coastal Resources

Bangkok 10210

Thailand
Julia Hwei Zhong Moh

Institute of Tropical Aquaculture and Fisheries

Universiti Malaysia Terengganu

21030 Kuala Terengganu, Terengganu Darul Iman

Malaysia

*Corresponding author; email: siriporn.pra@psu.ac.th

Received: 28 November 2020

Accepted: 5 February 2021 